\title{
TITLE:
}

\section{Interaction of Siomycin with the Acceptor Site of Escherichia coli Ribosomes(Abstract_要旨)}

\section{AUTHOR(S):}

Watanabe, Sachihiko

\section{CITATION:}

Watanabe, Sachihiko. Interaction of Siomycin with the Acceptor Site of Escherichia coli Ribosomes. 京都大学, 1972, 理学博士

ISSUE DATE:

1972-11-24

URL:

http://hdl.handle.net/2433/219870

RIGHT: 


\section{【85】}

氏 名

学位の種類 学位記番号 学位授与の日付 学位授与の要件 学位論文題目

渡 辺 幸 彦
斿だ方

理学博士

論 理 博 第 410 号

昭和 47 年 11 月 24 日

学位規則第 5 条第 2 項該当

\section{Interaction of Siomycin with the Acceptor Site of Escherichia coli Ribosomes}

（大腸菌リボゾームの acceptor 部位とシオマイシンとの相互作用）

論文調查委員教授由良隆教授高浪満教授香月裕彦

\section{論 文内容の 要旨}

細胞内顆粒リボゾームはずでての細胞生物に和いて遺伝子 DNA の情報をメッセンジャー RNAの仲 介によってそれぞれ特異的なタンパクに眽訳する場として広く知られて居りここのタンパク合成の過程で 特に転移 RNA が関与する機構は情報伝達の主要な局面として重要である。りボゾームに働きタンパク 合成を特異的に阻害する抗生物質はこの様な機構の解析に極めて有効な研究手段を与えるが，本論文はシ オマイシンがリボゾームに結合して如何にして転移 RNA の結合，転移，遊離に影響を与えるかを詳細 に検討した結果を扱っている。

先づ Deacylated tRNA で前処理したリボゾームへの N-acetylphenylalanyl tRNA の 結合はシオマ イシンによって阻害されることを見出し，その過程の解析からこの薬剤がリボゾームの Acceptor 部位 (A 部位) への tRNA の結合を阻害することを明らかにした。また deacylated tRNA で処理したリボ ゾームへ既に結合した N-acPhe-tRNA はシオマイシンを加えても遊離しないが，基質が EF-G 因子と GTP でプュロマイシンと反応出来る部位へ転移する反応はシオマイシンを基質の結合後に加えても著し い阻害を受ける。このことはリボゾームのA部位に N-acPhe-tRNA が存在してもシオマイシンはリボ ゾームと作用できることを示唆する。

次に高濃度 $\mathrm{NH}_{4}{ }^{+}$で N-acPhe-tRNA をリボゾームに結合させてから $\mathrm{NH}_{4}{ }^{+}$の濃度を下げると著し いtRNA の遊離が観察され，シオマイシンはこの遊離反応をも阻害することが判った。従ってA部位に tRNA が結合していても, 薬棛がリボゾームに働くという上記の推論は強く支持され，かつその作用は A 部位に影響を及ぼすことが明らかにされた。

以上の様な諸結果から, シオマイシンの作用点は A部位とは異なるリボゾーム上の部位であり，その部 位との相互作用の結果としてA部位に影響を与える様なリボゾームの高次構造の変化を誘起していること が示唆された。 


\section{論文審 査の結 果の要旨}

タンパク生合成に拈けるリボゾームの役割は，メッセンジャー RNA の情報をそれと対応するアミ， 酸の配列に翻訳し，ペプチド鎖として完成させることである。従って眽訳の場としてのリボゾームはペプ チド合成の開始，ペプチド鎖の伸長，ペプチド合成の終了の各段階に関与している。リボゾームの構造は 生化学, 物理化学並びに遺伝学の手法を用いて解析されつつあるが，それぞれの段階でのりボゾームの役 割と構造との対応については余り判っていない。

申請者は本論文に拾いて，抗生物質シオマイシンによりリボゾームがどの様な影響を受けるかを独自の 方法により詳細に検討した。まず，リボゾームを deacylated tRNA で前処理する方法を用いてリボゾー ム上の 2 つの tRNA 結合部位 (A及びP部位) に㧍の扮の選択的に AcPhe-tRNA を結合させること に成功した。この系を用いて，(1) シオマイシンがA部位への AcPhe-tRNA の結合を阻害すること， (2) A部位に AcPhe-tRNA を結合後に薬剤を加えても tRNA は遊離してこないこと，(3) シオマイシ ンはAcPhe-tRNA のA部位から P 部位への転移反応をも阻害することなどを見出した。これらの結果 からシオマイシンはリボゾームの A 部位に AcPhe-tRNA の存在すると否とに拘らず, リボゾームと作 用しうることが示唆された。

次に一旦A部位に結合した AcPhe-tRNA を $\mathrm{NH}_{4}{ }^{+}$濃度を変えてリボゾームから遊離させることに成 功し，その遊離反応がシオマイシンで阻害されることを見出した。この事実は上記の結果と合せてリボン゙ ームのA部位上の AcPhe-tRNA の存否に拘らずシオマイシンが A 部位に影響を及ぼすことを示すと同 時にこの楽剂の作用部位は $\mathrm{A}$ 部位以外の所にあることを暗示している。

以上の知見はシオマイシンがリボゾームの活性部位にいわゆるアロステリック効果を及ぼすことを意味 するもので，リボゾームのもつ柔軟かつ精巧な性質を解析する一つの手がかりを与えると同時に，抗生物 質などの阻害機構の研究にも新しい指針を与えるものとして高く評価される。

な扔参考論文は大部分が主論文の基礎となる知見あるいは主論文の内容を更に発展させた結果を含んで 扣り，タンパク質生合成分野に括ける申請者の一貫した深い研究態度，能力とその成果を示すものである。

よって, 本論文は理学博士の学位論文として価值めるものと認める。 